\title{
Research on Industrial Structure Optimization by the Promotion of Producer Service Industries in Wuhan
}

\author{
Lin Xiang ${ }^{1, \text { a }}$ \\ ${ }^{1}$ School of Business, Jianghan University, Wuhan 430056, China \\ 1509627354@qq.com
}

Keywords: industrial structure optimization; producer service industry; Wuhan

Abstract: The producer service industries push forward the optimization of the industrial structure, mainly in order to promote the rationalization and upgrading of the industrial structure. At present, there are some problems in the development of producer service industries in Wuhan, which, to some extent, hinders the process of optimization and upgrading the industrial structure. Therefore, it is necessary to formulate corresponding countermeasures to speed up the development of producer service industries.

\section{Introduction}

The producer services refer to services that can be used for goods and services rather than services for final consumption. The producer service industries are the industries in that producers receive services in the market specifically for production and business activities. According to the classification of the national economic sectors and the characteristics of the manufacturing sectors, the producer service industries closely related to manufacturing include transportation, warehousing and postal services, information transmission, computer services and software, finance, real estate, scientific research, technical services, geological prospecting, leasing and business services and so forth. The development of the producer service industries is the result of the further deepening of the whole social division of labor. It is mainly dependent on the development of the manufacturing industries, which run through the various links of the manufacturing industries, and plays an important role in the service of the enterprises before, during and after the production. At the same time, the producer service industries are pushing the development of new technology and new products. It can play a guiding role in the technological transformation and product innovation of manufacturing industries. From the perspective of industrial development, producer service industries have already taken an important position in the process of industrial structure optimization.

\section{Interaction between Producer Service Industries and Manufacturing Industries}

First of all, producer service industries promote the development of manufacturing industries, while manufacturing industries play a stimulating role in producer services. On the one hand, with the continuous adjustment of the industrial structure, the producer service industries run through the whole process of production. As a vector of new technology and knowledge, the producer service 
industries put human capital and knowledge capital into the manufacturing industries to reduce the cost of intermediate service required by the manufacturing industries, improve the competitiveness of the related products of manufacturing enterprises and guide the manufacturing sector to carry out technological innovation and upgrade the specialization level of manufacturing industries, which have promoted and guaranteed the development of manufacturing industries. Therefore, accelerating the development of the producer service industries can not only provide high level investment for the manufacturing industries, but also boost the transformation of scientific and technological achievements into realistic productivity, speed up industrial technology upgrading and product innovation to realize the industrialization by information technology. On the other hand, with the advancement of industrialization and the deepening of specialization among the manufacturing industries, the manufacturing production has become the development process of a series of service markets, such as product $\mathrm{R} \& \mathrm{D}$, warehousing and logistics, modern insurance, accounting and legal services, every step of which is accompanied by the demand for producer services. As the intermediate input element, producer services are integrated into the manufacturing industries, creating a demand space for the development of the producer service industries. The development of manufacturing industries, the enhancement of the competitiveness of the manufacturing industries and the upgrading of the manufacturing industry structure will also require the support of the producer service industries such as design, planning and technology research and development. Manufacturing industry is the premise and foundation for the development of producer services, and it promotes the development of producer services.

Secondly, the development of producer service industries also has a full range of radiation capabilities. Producer services can influence the whole industry's value chain and realize the cross regional and cross industry development models.

Thirdly, from the micro perspective, the development of producer services can strengthen the sense of independent innovation and enhance the ability of independent innovation of enterprises. Now China faces not only the problem of lack of innovation ability and the low added value of the product, domestic resources shortage and environmental pollution, but also the constraints of foreign countries' technical barriers. So improving the sense of independent innovation and independent innovation is of great significance for the realization of the strategy of building an innovative country. The development process of manufacturing, design, logistics and brand strategy have been widely integrated into the components of the producer service industry. The producer services will have a great impact on the innovation of each segment of the enterprises.

\section{Problems}

In Wuhan, the manufacturing industries have not provided an opportunity for the development of producer services. As a traditional industrial city, Wuhan has always been the main force to stimulate economic growth. However, the traditional industries account for a big share of the manufacturing industries, which have characteristics of high energy consumption, low value-added and low labor productivity. The proportion of $\mathrm{R} \& \mathrm{D}$ and production still needs to be promoted, that is, a considerable part of the manufacturing enterprises are engaged in the producing segment of "smile curve", which only represents a small part of the value of the industrial chain, and the intermediate demand for the producer service industries is not sufficient. The low end development of the manufacturing industry restricts the development of the producer service industries and the upgrading of the core competitiveness of the manufacturing industries themselves. The development of producer services is lagging behind and does not meet the needs of manufacturing industries. In recent years, the service industries in Wuhan have developed rapidly, but from the internal structure of the service industries, they are only the traditional low value-added service 
industries. The producer service industries with high value-added and high technology content have developed slowly, and the proportion of the service industries is still low. The development of the producer service industries is lagging behind and the level of supply is low. It does not meet the needs of the specialization of the manufacturing enterprises, keep up with the overall development speed of the economy, and play a proper supporting role in the development of manufacturing industry. The producer services and manufacturing industries in Wuhan are not highly correlated with each other, and the benign interaction mechanism has not been formed yet.

According to some industrial policies, the market access threshold of some industries (financial, technical services, etc.) in the producer service industries is so high that it leads to the low degree of market-orient of the producer services. It is difficult for the vast majority of potential investors to enter the industry, especially the private capital and foreign capital, which weakens the basic role of the competition mechanism in the development of industrial development. The result of the low market level is the lack of innovation ability in the development of the producer service industries, the low efficiency of the service and the quality of service provided, and the higher price level of the service compared with the international market. The characteristics of market supply and demand and the cost and benefit of the enterprises do not truly reflect the market. It also leads to the non-standard market competition, increases the market transaction cost, restrains and weakens the development level of the producer service industries.

\section{Countermeasures}

Firstly, the government should provide support for the development of producer services by taking innovative institutional arrangements. It is important to improve the policy system of the producer service industries including fiscal and tax policy, financial policy, land policy, energy supply policy, price policy and human resource policy, which help producer services lead the leverage mechanism to support the weak links, key and emerging areas of producer service industries in Wuhan.

Secondly, we should promote the interaction between producer services and manufacturing. Based on the characteristics of the manufacturing industry and the development of the producer service industry, manufacturing industry can drive the development of producer service industries and create a "manufacturing service platform" based on manufacturing. Manufacturing service platform means a mechanism to make use of the advantages of the existing manufacturing industry cluster, to form a relatively independent specialized structure and a productive service platform by integrating other service organizations for the internal service of the enterprises. This platform can attract other producer service enterprises to gather around the platform, form a cluster of producer service industries, which can greatly promote the development of producer services.

Thirdly, we must attach importance to training and introducing high-quality talents in the service industries. With the development of the producer service industries, the relative shortage of professional talents in service sectors highlights the problem of the shortage of human capital in these sectors. Wuhan city has so many advantages of the abundant resources of the university scientific research institutes and vocational schools that it can entrust these institutions and schools to cultivate high-quality talents in the service industries to meet the needs of the market. We should improve the corresponding incentive mechanism and retention system, and establish a reserve mechanism for talent resources. It is crucial to encourage and attract domestic and abroad professional talents, and attach more importance to introducing advanced technology and experience from developed countries to enhance the management level of producer service industry in Wuhan. 


\section{References}

[1] Chuanqing Wu, Chenchen Zhou, Research on the Mechanism of Promotion of Industrial Structure Optimization by Producer Service Industries, Review of Regional Economy. 2 (2014) 43-48.

[2] Jianjun Chen, Jingjing Chen, Research on the Integration and Positioning of Producer Service Industries and Manufacturing Industries, China Industrial Economics. 6 (2011) 26-32.

[3] Ping Li, Yifu Fu, Yanfang Zhang, Do Producer Service Industries Become the New Motivation of High Quality Economic Growth in China, China Industrial Economics. 12 (2017) 96-102.

[4] Derui Du, Zhe Zhang, Lijuan Yang, Research on the Influence Elements on Producer Service Industries Based on the Process of Industrialization, Shanghai Economy Review. 1 (2014) 66-72.

[5] Yuan Zhou, Review of the Functions of Producer Service Industries to Upgrading the Competitiveness of Manufacturing Industries in China, Proceedings of 2014 International Conference on Psychology and Public Health (PPH 2014), vol. 5. 